\title{
Utilisation of information technology to support information and knowledge management by lawyers in Polokwane City
}

\author{
Solomon Bopape' \\ University of South Africa, Department of Library Services \\ bopapst@unisa.ac.za
}

Received: 10 June

Accepted: 10 November 2010

\begin{abstract}
A revolution in information and communication technology is taking place in the world. With this technological revolution, information and knowledge are also considered as crucial assets for every organization. Law firms are regarded as one of the industries which are information and knowledge-intensive. The utilization of information technology can play an essential role in supporting information and knowledge management in law firms. An investigation into the extent to which lawyers or law firms in Polokwane city utilize information technology to support information and knowledge management was conducted through a survey questionnaire based on the Technology Acceptance Model. The findings of this research showed that lawyers utilise information technology systems or applications that are common, such as word processing, e-mail, client billing and online databases for searching legal information. Other information and knowledge management tools, such as Intranets, extranets and web portals, were the least and non-utilised applications by these lawyers. The main reason for non-utilization of such systems may be linked to non- exposure to information technology and unfamiliarity with information and knowledge management tools. It is, therefore, recommended that legal schools should include, in their curriculum, modules on the application and role of information technology in the legal practice. Recommendations for future research related to this subject are also provided.
\end{abstract}

Keywords: Information management; information technology; knowledge management; lawyers and law firms

\section{Introduction}

The presence of information and communication technologies in organisations has expanded significantly to a point where there is no organization that can function without these tools. Coupled with this expansion is an increasing recognition of information and knowledge as indispensable and valuable assets in every organisation (Parsons 2004: 3). The success of every organisation depends largely on how well it uses information technology to manage its information and knowledge resources (Cascio 2001:15). Law firms represent an industry which is appropriate for information and knowledge management ( $\&$ KM) investigation, because their work revolves around information and knowledge (Gottschalk 2002:1/5). In this study, emphasis was, therefore, placed on law firms as information and knowledge intensive organizations and on the extent to which information technology is utilised to support of management of these resources, i.e., information and knowledge, in law firms. The market of providing sophisticated legal services in the era of information and knowledge society is competitive. Singh et al., (2002) mentioned that most individual, corporate and commercial clients for lawyers are fast becoming computer literate and are keen to communicate their queries electronically with their legal representatives. They are, therefore, forcing legal professionals to invest more in information and communication technologies. Mountain (2002: 1066) made reference to a digital delivery service of the human legal product delivered by digital means, for example, distributing legal documents through e-mail. Du Plessis (2004:4I) also stressed that lawyers should be able to have access to information and knowledge generated in the course of relationships with their clients, so that they should be used again in other cases or when required in future. Schlein (2003:3) encourages law firms to have a domain name or web sites because their potential clients have become more sophisticated and want to check out their lawyers on the web before assigning tasks to them.

Several authors, therefore, agree that advances in information technology are transforming the methods that lawyers can use to generate, access, retrieve, process, and share information and knowledge in order to deliver legal services to their clients. Gottschalk (2000:1 I6) confirmed that the use of information technology enables them to take advantage of the most appropriate tools to improve efficiency, increase effectiveness, streamline communication, and reduce costs to their clients. Duncan (1997:I) asserted that information technology is a powerful tool, which can manipulate information and knowledge, the stock-in-trade of the legal profession. Lawyers are producers, processors, managers, and purveyors of information and knowledge. Their main tasks have, therefore, been summarised as information collection and retrieval, communication of information, information management, research, evaluation of information and knowledge management. The use of information technology can help them to perform all these tasks (Fombad \& Moahi 2005:225).

I. Solomon Bopape $(\mathrm{PhD})$ is a Personal Librarian for the School of Law, University of South Africa, Department of Library Services. 
Managing and using I and KM technologies efficiently and productively are, therefore, core competencies for lawyers (Edwards \& Mahling 1997: 158). Du Plessis (2004:14) also stated that the functions and possibilities of the new information technologies are enabling lawyers to manage information and knowledge in order to become increasingly more efficient and effective in their practices.

Despite the recognition of the benefits and advantages of utilizing IT in the legal practice, there is little empirical research that has been done on the actual utilization of information technology to support I and KM in law firms. This study was subsequently an attempt to supplement existing empirical research on the actual utilization of information technology to support I and KM by lawyers, as well as to stimulate future research on the subject, particularly in South Africa. The studies that empirically examined the utilization of information technology in law firms concur with the sentiment that lawyers are poor users of information technology. Singh et al., (2002), for example, confirmed the legal practice seems to be a predominantly paper-based profession and that legal professionals seem to be moving slowly in embracing the information age. Wall (1998) stated that the legal profession is still largely dependent on the physical circulation of information in a paper-based format, from one party to the other. Kennedy (2002) also affirmed that while the vendors of software packages and other information technologies consistently perceive the legal profession as a fertile market for their new advanced products and initiatives, they are often disappointed by the resistance they receive from the lawyers and law firms. Staudt (2003) pointed out that since the beginning of the office technology boom in the 1980s lawyers have been accused of being fearful and reluctant to adopt modern technology. Jenkings (2008) observed that lawyers seem to have lagged behind, when compared to other professions.

This study, therefore, considered that there could be a number of factors attributable to poor usage of information technology to support I and KM by the legal professionals. An attempt was subsequently made to determine what those factors are by examining the extent in technological usage to support I and KM among the lawyers. Lawyers attached to law firms in Polokwane City were chosen as the test for the study. Polokwane is the capital city of Limpopo Province and is the main city where most of the lawyers are operating. The city was specifically chosen as the area for the study because the researcher was cognisant of the fact that the costs of gathering data and information in the area where one resides might be minimal.

The main research question that needed to be answered in this research was to what extent do lawyers attached to law firms in the city of Polokwane utilize information technology to support I and KM activities in their daily operations? The specific objectives of this study were to establish:

- The variables that influence usage of information technology to support I and KM by the lawyers in Polokwane;

- Purposes for which the lawyers in the city utilize information technology;

- Knowledge and competencies of lawyers in the city with regard to I and KM technology concepts and applications; and

- The attitudes and culture of lawyers in the city towards I and KM technologies.

\section{Literature review}

Du Plessis and Du Toit (2005) spelled out that information in law firms subsists in legal information sources such as legal reference works, indexes, digests, casebooks, law reviews, legal periodicals, and academic works of legal researchers, commentaries, books, and articles from specialised law publications. Information management in law firms can be therefore be defined as the activities by which information resources are collected, registered, indexed, organised, used, controlled, stored, retrieved, disposed and disseminated to people inside and outside the firm. Knowledge in the practice of law is knowledge about the law itself and its applications which are used to procure, to produce and to manage legal work. Knowledge Management in law firms is about providing the firm's lawyers and staff with cost effective tools to support daily processes through which an understanding of "the law", "the world", and "the client" is created, organised and shared (Du Plessis \& Du Toit 2005). Knowledge management include the way in which policies and procedures, precedents of the firms, conference papers, useful opinions and advices (best practices), documents, memorandum, briefs, forms, court transcripts, in-house databases, external databases, etc, are generated, organised and disseminated for future use in the law firm. For the purpose of this work I and KM can, therefore, be defined as the creation and acquisition; organization and storage; as well as distribution and sharing of information and knowledge within the firm. The main purpose of I and KM is to help lawyers to create business information and knowledge, to organize and make them available whenever they are needed (Tseng 2008: 150).

Information and KM activities require the support of a technical infrastructure, that is, information technology, to take place. This includes the hardware and software used to capture, store, organise, retrieve, process, and transmit data. One of the main roles of information technology in I and KM, therefore, is to accelerate the speed of information and knowledge creation, storage, organization and distribution (Cascio, 200I:15). Information technology in this research, therefore, refers to the tools that enable the handling of information and knowledge and then facilitate different forms of 
communication that are computer-based, including capturing, storage and processing, transfer, and communication technologies. I and KM tools that can be used in a law office includes general office applications, specialised law office applications, proprietary online services and web technologies.

- Widdison (1997) refers to general office applications such as the Microsoft office suite applications, namely, word processing, Excel spreadsheet, Access and PowerPoint.

- Specialised law office applications are specifically designed for the law office timekeeping and billing applications and for litigation support. Some examples of such applications are the programmes called Elite for timekeeping and the programme known as Summation for used litigation support.

- Proprietary online systems are typically used for legal research purposes, which enable lawyers to access legal information sources such as legislation, case law, and legal articles through the use of the internet (Griffith, I998: I4). Online databases services such as Heinonline, Lexis-Nexis, Jutastat, Westlaw etc have become firmly entrenched legal research tools (Jenkins 2008).

- Finally, web technologies including intranets, extranets, e-mail and knowledge portals, which are basically used for communication purposes through the internet.

When looking for literature on utilization of information technology to support I and KM in South Africa, it becomes apparent that the topic has received more attention in the manufacturing industry than in the legal industry (Ndlela \& Du toit, 200I:I5I-165; Botha \& Fouche, 2002:I3-19; Newman, 1999; du Toit, 2003:III-I20; Du Plessis \& Boon, 2004:7386; Steyn, 2003:206-228). Most of these works represent the findings of the research projects on I and KM practices in the South African business sector. The works (dissertations) that were available, at the time of conducting this research regarding I and KM in South African law firms were by Du Plessis (2004) and Archbold (1998). The latter investigated the role of $\mathrm{I}$ and $\mathrm{KM}$ in support of legal research in the digital environment, whilst the former investigated the extent to which law firms in South Africa have transformed their business by using TCP/ IP based applications such as the intranets, extranets, home pages and internet browsers to improve their services. The other works by Du Plessis and Du Toit (2005; 2006:360-37I) observed that the adoption of information technology to support I and KM in law firms is still in its infancy in South Africa. These research works maintained that lawyers, even if they might not realise it, are using I and KM techniques when they capture the knowledge they have acquired and reuse it the next time they have to draft a contract, pleading, or trust. Du Plessis (2004:7I) also observed that law firms might be passively or unconsciously practicing I and KM by sharing information, for example, when a legal question arises, to some the first reflex will be to look up the case law or ask someone in the firm who has dealt with similar issues or others may consult their document management system or perform word searches on the firm's previous work products.

\section{Research methodology}

The nature of research approach employed in this study was an empirical quantitative survey, through the questionnaire, based on Technology Acceptance Model (TAM). TAM, advanced by Davis (1989:319-339) was rooted in the Theory of Reasoned Action, proposed by Fishbein and Ajzen (1975). The model postulates that "perceived usefulness" and "perceived ease of use" influence attitudes to computer technologies, which in turn influence technology usage. The latter is defined as the way in which using a particular system will increase job performance in organisational context and the former as the degree to which the user is free from effort, in terms of physical and mental effort as well as ease of learning (Venkatesh \& Bala 2008: 275). According to TAM, these two beliefs, that is, "perceived usefulness" and "perceived ease of use", determine one's intention to use computers and related technologies. The model is therefore, based on the assumption that usage or non-usage of information technology can only be recognized if attitudes towards computers or satisfaction in using computers are investigated (Colvin \& Goh 2005: 90). Applying this explanation to the context of this study suggests that a lawyer who is using information technology is someone who is receptive to its usage and open to the purported benefits of utilizing information technology. If the use of computers within legal practice is to be considered desirable, lawyers must first be receptive to the presence and benefits of computers.

According to TAM, other factors that influence the utilization of computer technology by individuals or groups of individuals are organizational support, satisfaction with information technology and perceived benefits (Western et al 200 I:I0-II). Organizational support is understood as the attitude of an individual's organization towards information technology and the material support that one's organization provides to encourage adoption and use of information technology. The kind of support that an organization may provide to the individuals within it includes training on the use of computers, material support, adapting to technological changes in the environment etc. Satisfaction with using information technology is strongly dependent upon the user's background, especially his/her past experience with computers and the skills acquired as a result (Western et al 200I:II). This implies that experience and skills of using information technology are positively associated with end user satisfaction and users with little experience and poor skills in using computers are less likely to embrace information technology.

SA Jnl Libs \& Info Sci 2010, 76(2) 
A questionnaire based on TAM, thus, contained five sections. Section A solicited information about the variables that might have an influence on the extent of information technology usage among the target population. These variables included background, age, year of qualification as lawyer, as well as previous computer experience and training. Information about the size of law firms and the existence I and KM positions such as librarian, information officer, knowledge manager, information manager, and documents manager in each law firm were also sought. Section B investigated the purposes for which information technology, in particular computers in the law firms, were used. Such purposes included word-processing, research, accounting, billing, case management, intranets, portals and electronic mail (e-mail).

Section $C$ of the questionnaire focussed on the attitudes of the lawyers with regard to the use of information technology in their law firms. Likert scaling was used to measure the attitudes of lawyers towards the importance information technology in law firms on a five-point scale score. Section $D$ of the questionnaire attempted to establish the extent to which these legal practitioners were familiar and competent with I and KM concepts and applications, by asking them about the extent to which they know about these concepts and applications. There were five possible answer options ranging from "to a very large extent" to "to no extent at all". Section E of the questionnaire attempted to determine the culture of law firms with regard to I and KM technologies. The respondents were asked to answer questions about the frequencies with which I and KM activities were discussed or assessed in their law firms.

\section{Results and discussion}

\subsection{Response rate}

Lawyers surveyed in the research were identified from a list of law firms by the Law Society of the Northern Province, Circle Council of Limpopo. Sixty (60) legal firms were listed as operating in Polokwane city and thus sixty (60) questionnaires were hand delivered to the office of the then Vice President of the Law Society of the Northern Province, Circle Council of Limpopo who distributed them through internal mail. Out of sixty the (60) questionnaires that were distributed, twenty-three (38\%) completed questionnaires were returned to the researcher. The results of this research may not be representative of all lawyers in Polokwane city due to poor response rate. One of the reasons for poor response rate might have been the time required to complete the questionnaires on the part of most lawyers. The nature of the job of lawyers is very demanding. Lawyers spend much of their time in court, and when they are in their offices they prepare for upcoming cases amongst other tasks. Riley (2005:2) noted that lawyers generally bill their clients at hourly rates and are thus inclined to be reluctant to engage in non-billable activities, such as completing a questionnaire.

\subsection{Factors affecting usage or non-usage of IT}

\subsection{Type of settlement}

Of the twenty three (23) respondents, II (48\%) of them, came from rural areas, whereas $8(35 \%)$ respondents came from the city of Polokwane itself, and 4 (17\%) came from urban townships in the locality of Polokwane (Table I). This shows that most of the lawyers operating in the city were residing rural areas, where they might have had no access to digital technologies. Whitcare (2010: 1283) pointed out that people from rural communities are disadvantaged in terms of information technology and Internet access, because most rural villages lack technological infrastructure. Although they are practising legal work in the city, where the technological infrastructure is more sophisticated and advanced, there is always a gap that exists between those who reside in rural villages and those who reside in the city itself, that is, in terms exposure to information technology. Their usage of information technology is poor because people with little or no exposure to computers are less likely to embrace information technology as Western (200I: 10) pointed out.

\subsubsection{Age and generation}

In terms of age, the results (Table I) showed that 10 (44\%) respondents belonged to the age group 36 to 45 years old. The same number of respondents, 6 (26\%) belonged in 26 to 35 year age group and the 46 to 55 year age group. Only I (4\%) was between 56 and 65 years. No respondents were under 25 years of age or older than 65 years of age. These results showed that the majority of the lawyers in this study fall within the age groups of Baby Boomers and Generation Xers. 
Table I Factor influencing IT usage

\begin{tabular}{|c|c|c|c|}
\hline Variable & Response & No. & Percentage (\%) \\
\hline \multirow[t]{5}{*}{ Type of settlement } & City & 8 & $35 \%$ \\
\hline & Rural & $\mathrm{II}$ & $48 \%$ \\
\hline & Urban township & 4 & $17 \%$ \\
\hline & Other & 0 & $0 \%$ \\
\hline & Total & 23 & $100 \%$ \\
\hline \multirow[t]{7}{*}{ Age ranges of respondents } & Below 25 & 0 & 0 \\
\hline & Between $26-35$ & 6 & $26 \%$ \\
\hline & Between $36-45$ & 10 & $44 \%$ \\
\hline & Between $46-55$ & 6 & $26 \%$ \\
\hline & Between $56-65$ & $I$ & $4 \%$ \\
\hline & Above 60 & 0 & \\
\hline & Total & $\mathbf{N}=\mathbf{2 3}$ & $100 \%$ \\
\hline \multirow[t]{7}{*}{ Year of qualification as lawyer } & Before 1970 & 0 & 0 \\
\hline & Between I97I - I980 & 2 & $9 \%$ \\
\hline & Between I98I - 1990 & 13 & $57 \%$ \\
\hline & Between |99| - 2000 & 4 & $17 \%$ \\
\hline & Between 200I - 2004 & 3 & $13 \%$ \\
\hline & After 2004 & $I$ & $1 \%$ \\
\hline & Total & $\mathbf{N}=\mathbf{2 3}$ & 100 \\
\hline \multirow[t]{5}{*}{ Number of Partners } & Between I - 5 & 19 & $83 \%$ \\
\hline & Between $6-10$ & 4 & $17 \%$ \\
\hline & More than II & 0 & 0 \\
\hline & Unsure & 0 & 0 \\
\hline & Total & $\mathrm{N}=23$ & $100 \%$ \\
\hline \multirow[t]{3}{*}{ Branch availability } & Yes & 7 & $26 \%$ \\
\hline & No & 17 & $74 \%$ \\
\hline & Total & $\mathbf{N}=\mathbf{2 3}$ & $100 \%$ \\
\hline
\end{tabular}

According to Codrington (2004:36), baby boomers grew up in the era of information technology, but are not entirely reliant on information technology, whereas Xers have been exposed to computers and seem to be comfortable with a variety of electronic equipment. One might generalise by stating this study was concentrated on participants who have a common direction towards information technology. The respondents were also asked to indicate the year in which they qualified as lawyers. More than half of the respondents, I 3 (57\%) qualified as lawyers between 198 I and I990 whilst 4 (I7\%) respondents qualifies as lawyers between I99I and 2000. Those who qualified as lawyers between $200 \mathrm{I}$ and 2004 represent 3 (13\%) of the respondents whilst 2 (9\%) respondents qualified as lawyers between I97I and I980. Only I (4\%) respondent qualified as a lawyer after 2004 and there were no respondent(s) who qualified before 1970, as shown in table $I$ above. The study revealed that most of the lawyers completed their legal degrees or qualified during the period when most of the organizational systems were being automated or computerised, that is, between I980 and I990. It can therefore be stated that most of the lawyers in this study were at least exposed to computers when they entered the job market.

\subsubsection{Sizes of law firms}

Respondents were asked to indicate the number of partners or fee-earners in their law firms. Responses by 19 (83\%) of the respondents showed that the law firms were small with I to 5 partners as against 4 (I7\%) of the respondents indicating their comprised 6 to 10 partners. The respondents were also asked to indicate if their law firms had branches. The majority of law firms by represented by 17 (74\%) respondents had no branches as against 6 (26\%) law firms which had branches. It has therefore been found in this study that most of the law firms are small. Singh et al (2002) argues that small law firms are not inclined to utilize information technology because they lack the financial muscle to purchase more advanced or sophisticated technologies. The study conducted by Moahi and Fombad (2005:23I), also pointed limited financial resources as one of the factors that impede the adoption and utilization of information technology by lawyers.

SA JnI Libs \& Info Sci 2010, 76(2) 


\subsubsection{Previous computer training}

The respondents were asked to indicate where they had computer training: at school, university, computer school or on the job. As is shown in figure I, most of the respondents $16(69 \%)$, did not have any formal computer training prior to their entering the workplace. It is vital to note that positive attitudes towards information technology arise only through access to training on the use of such equipment. According to Western et al. (200I:10), people with no computer training are less inclined to use computers than those who have computer training.

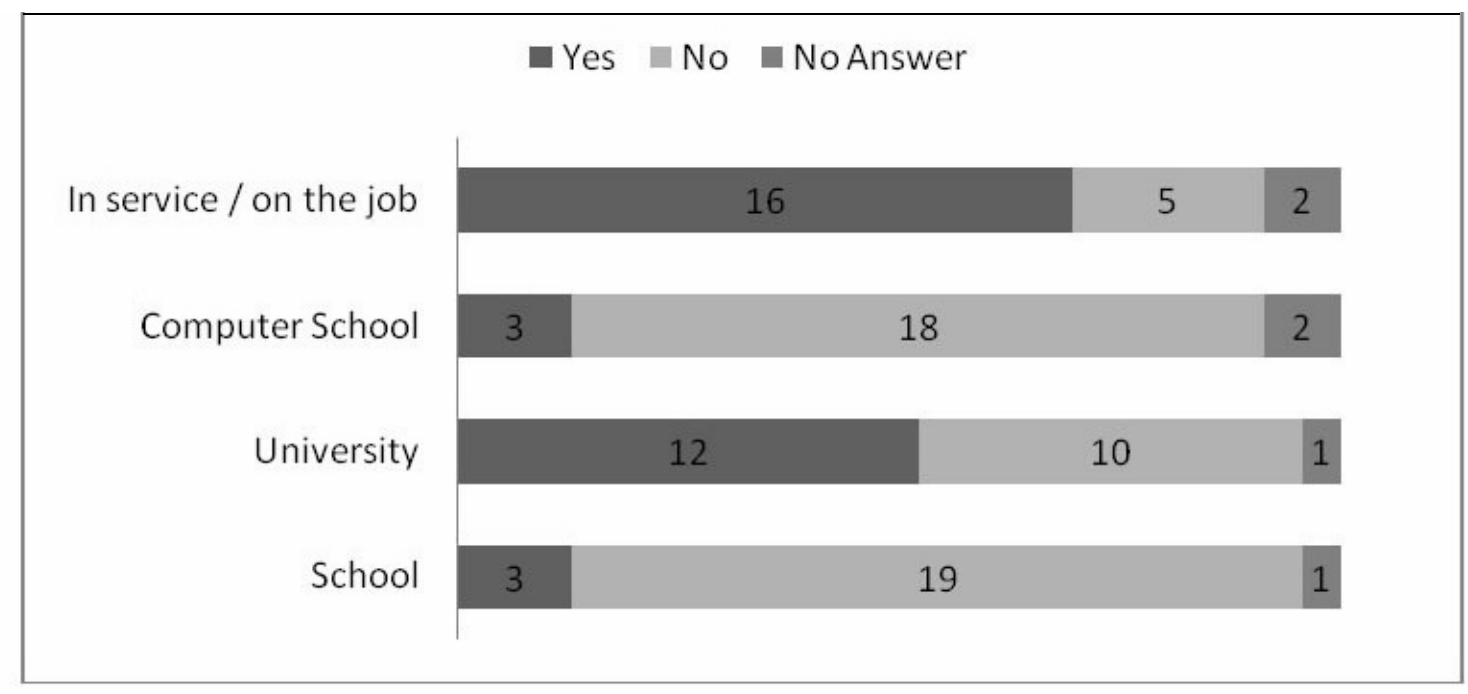

Figure 1 Previous computer training $(\mathrm{N}=23)$

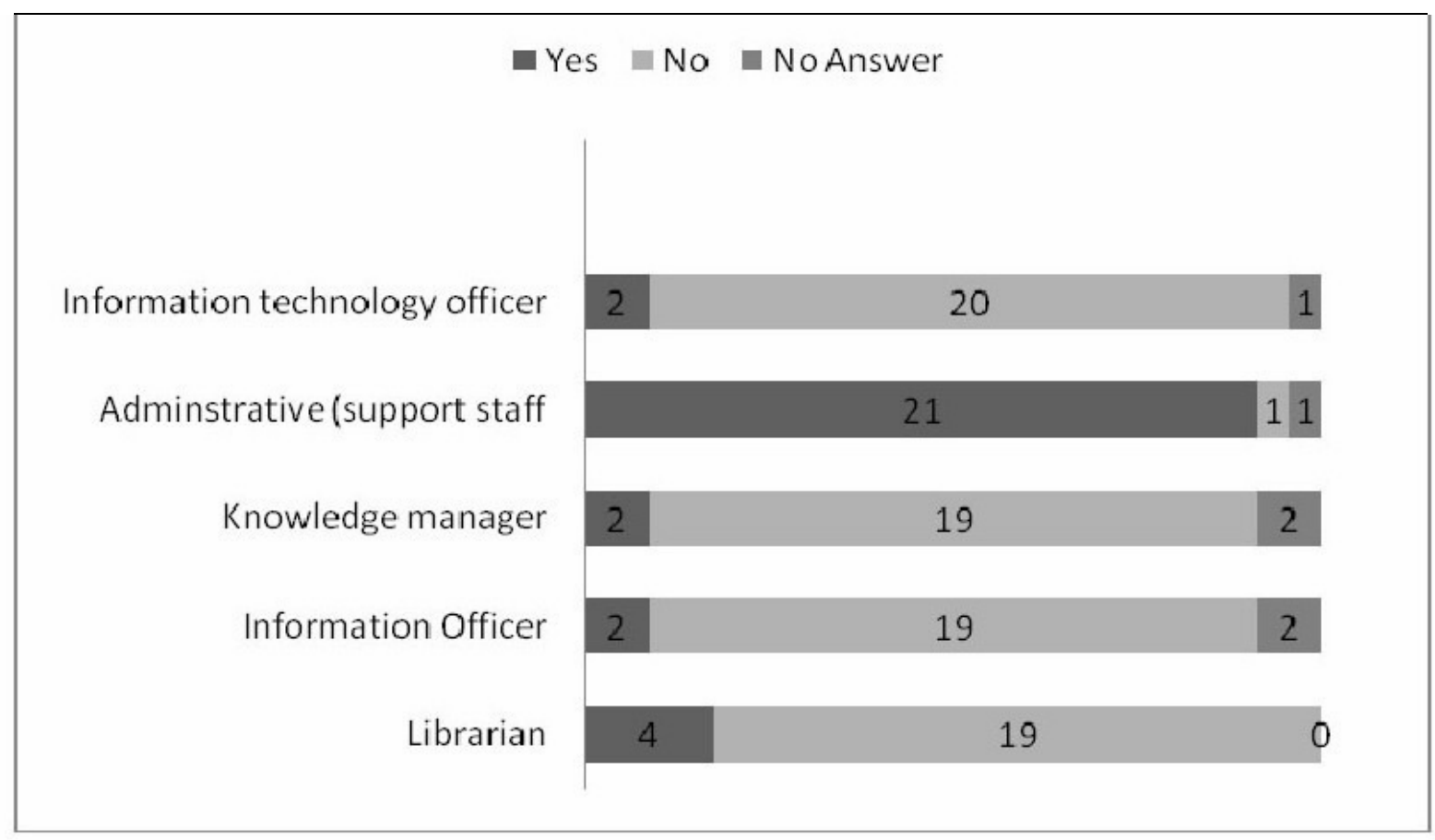

Figure 2 Existence of information and KM positions $(\mathrm{N}=23)$ 


\subsubsection{Existence of information and $\mathrm{KM}$ positions}

The respondents were asked to indicate if positions existed in their organizational structures for staff responsible for $I$ and KM functions. The results (figure 2) indicate that most of the law firms did not have people responsible for I and KM functions. The majority of the firms had only administrative or support staff in their employ, with 21 (92\%) of the respondents. Staudt (2003) confirms that lawyers delegate most of their computer-related tasks to the administrative staff or secretaries, whilst they themselves deal with professional tasks like legal research and legal counsel.

Meyerowitz (2003:I) argues that a key player in any law firm's I and KM function should be the firm's librarian or information officer. The role of the librarian or information officer in the law firm is to ensure that information and knowledge in the law firm are arranged in such a way that users are able to identify and retrieve them with ease. Since most of the firms in this study do not have librarians, information officers or knowledge managers, it was found that most of them do not have I and KM tools such as intranet, extranets and web portals.

\subsection{Purposes for utilization of IT}

This section considers the purposes for which law firms utilize information technology. It was found that most of the respondents used computers in their law firms for e-mail and word-processing with 21 (9l\%) respondents each, Internet research and client billing with 20 (87\%) respondents each and case management with 19 (83\%).

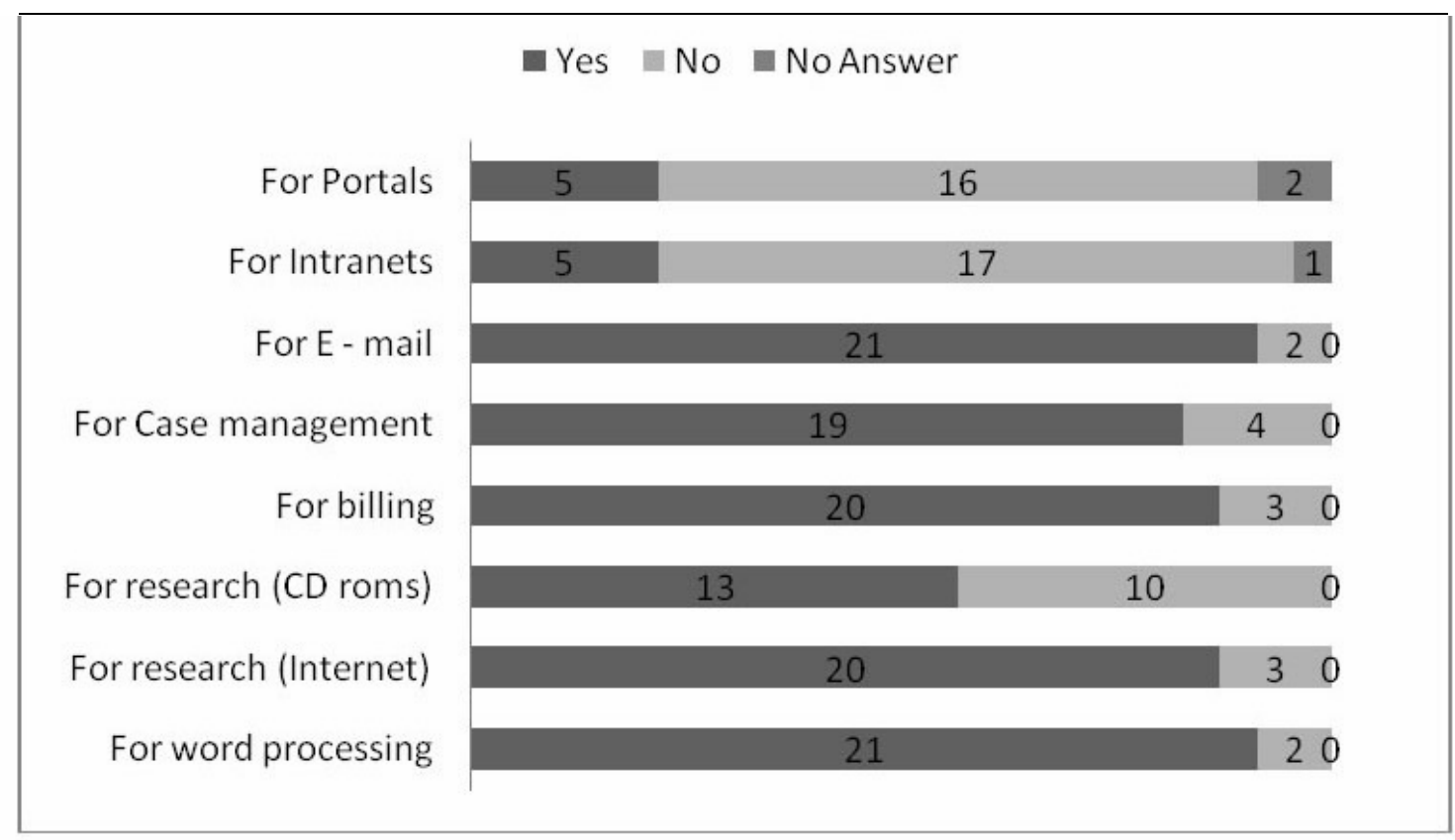

Figure 3 Purposes for utilizing IT $(\mathrm{N}=23)$

Effective communication through the use of e-mail has become a critical success factor for law firms. Due to trends of globalization, collaboration, outsourcing, the knowledge economy etc, the use of e-mail has increased in law firms (Hofman 1997:21). Word processing was also widely used in law firms because every legal document, be it letters, contracts, wills, cases, deeds, and pleadings is the by-product of word processing or typing activities (Shuey 1990:90). Legal work revolves around production of documentation; it is therefore not surprising that word-processing was the most frequently used application (Wall \& Johnstone 1997: 120). Utilization of information technology for research and database access showed that most of the lawyers endeavour to keep abreast of latest developments in law. Du Plessis and Du Toit (2005) stressed that legal research is one of the critical skills that lawyers employ on behalf of their clients and that competency in legal research is essential to any lawyer. The lawyers have a professional responsibility to do research and know the law to serve the clients and the public's best interest. The use of information technology for client billing showed that in any law firm, there is a substantial amount of administration that needs to be done. Apart from marketing the law firm, another important administrative task is that of client billing or accounting. Periodic billing can be generated automatically by a law firm's accounts system and then communicated electronically to the client (Widdinson 1995:9). 
Case management software contains client information, notice dates, court dates, follow-tasks and appointments. It serves as storehouse for data related to cases for which the law firms are responsible. Case Management is, therefore, very important for lawyers because it helps them not to miss their appointments or their important assignments and to manage their workflow.

Intranets, extranets and web portals were the least and non-utilised tools by most of the participants. Intranets were used by $5(22 \%)$ of the respondents whereas $17(74 \%)$ respondents did not use them. The respondent, I (3\%) of the respondents did not give an answer. Web portals were also used by $5(22 \%)$ respondents as against 16 (69\%) respondents who did not use them their firms. The remaining 2 (9\%) did not answer the question. Cloete and Snyman (2004:47) accounted that we are in the middle of the information age, suffering from information overload on the one hand and a lack of knowledge on the other. It is, therefore, speculated that lawyers might also be suffering from lack of knowledge about I \& KM tools such as intranets, extranets, and web portals. Bennet (2006) also maintains that although most lawyers can turn on computers, send and receive e-mails, create documents, surf the internet, more advanced functions are often reserved for information technology specialists. Unfortunately, most of the law firms employed secretaries and administrative staff rather than I and KM professionals as shown in figure 2.

\subsection{Attitudes of lawyers towards IT}

Section $C$ of the questionnaire focused on the attitudes of lawyers towards information technology in their law firms or offices. They were asked about the degree of importance they attach to the utilization of computers in their law firms. Of the five answer options ranging from "not important at all" to "very important", only two options were answered by the respondents (figure 4). The majority of respondents, that is, 19 (83\%) viewed the use of computers as "very important" in law firms, followed by 4 (I7\%) of respondents who viewed the use of computers in law firms as only "important". None of the respondents viewed computers in law firms as "not important" or as "not important at all".

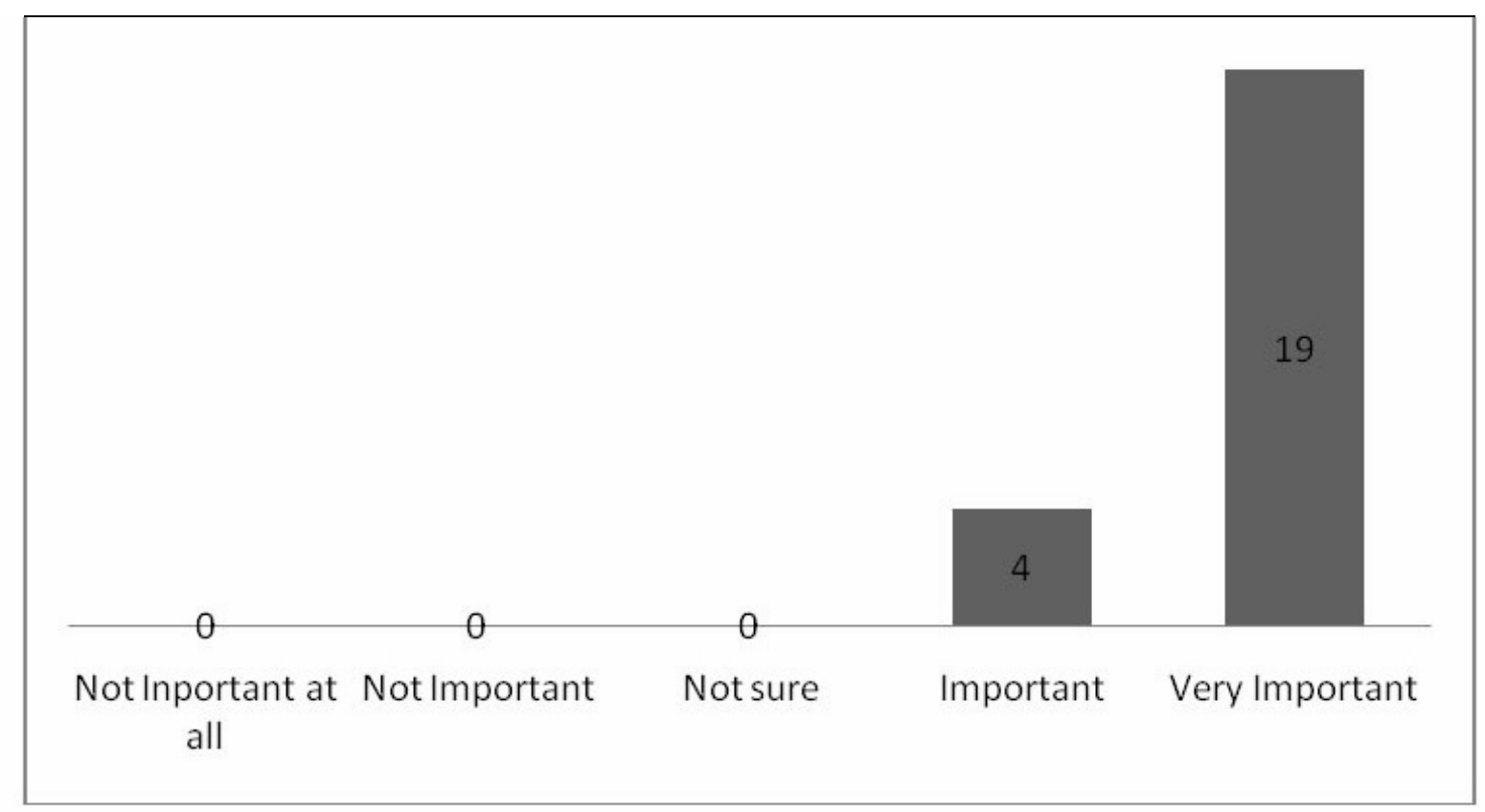

Figure 4 Importance of IT in Law Firms $(\mathrm{N}=23)$

The attitudes of individuals towards information technology system can also play an important role in influencing their subsequent behaviour towards it (Al-Gahtani \& King, 1999:277). The overall acceptance of the role information technology in law firms was revealed in the results above, which means that lawyers accept that computers are important and useful tools for law firms. The only setback that seems to be holding them back from exposing their positive attitudes towards information technology is that most of them did not receive any training on the use of computers as shown in figure I. 
4.5 Familiarity with IT concepts and applications

Section $D$ of the questionnaire sought to establish the extent to which the respondents were familiar with some information and knowledge management concepts and applications. E- Mail appeared to be one of the tools which is known "to a very large extent" by most participants, represented by II (49\%) respondents. This shows that e-mail is the most important tool in law firms because it increases cooperation not only with colleagues but with other lawyers in the surrounding area, as well as with the clients. It is very simple to understand and just like the 'good old letter', e-mail solves two basic problems of communication, namely, the problem of traveling and that of synchronization (Shuey, 199l: 90).

Table 2 Extent of familiarity with I \& KM tools and applications $(\mathrm{N}=23)$

\begin{tabular}{|c|c|c|c|c|c|c|}
\hline Tools \& applications & $\begin{array}{l}\text { To no extent } \\
\text { at all }\end{array}$ & To no extent & $\begin{array}{l}\text { To some } \\
\text { extent }\end{array}$ & $\begin{array}{l}\text { To a large } \\
\text { extent }\end{array}$ & $\begin{array}{l}\text { To a very } \\
\text { large extent }\end{array}$ & No Answer \\
\hline Spreadsheet & 3 & 4 & 12 & 2 & $\mathrm{I}$ & $\mathrm{I}$ \\
\hline Word processing & $\mathrm{I}$ & 3 & 2 & 8 & 7 & 2 \\
\hline$E-$ mail & 1 & 2 & 4 & 4 & II & $\mathrm{I}$ \\
\hline Intranets & 8 & 7 & 4 & 2 & 2 & 0 \\
\hline PowerPoint & 5 & 2 & II & 3 & I & I \\
\hline Internet & 2 & 3 & 8 & 4 & 6 & 0 \\
\hline Billing Software & 2 & $\mathrm{I}$ & 3 & 13 & 3 & $\mathrm{I}$ \\
\hline Online searching & 2 & 5 & 3 & 10 & 2 & I \\
\hline CD Roms & I & 3 & 10 & 5 & 4 & 0 \\
\hline Case management systems & I & 2 & 5 & II & 3 & I \\
\hline
\end{tabular}

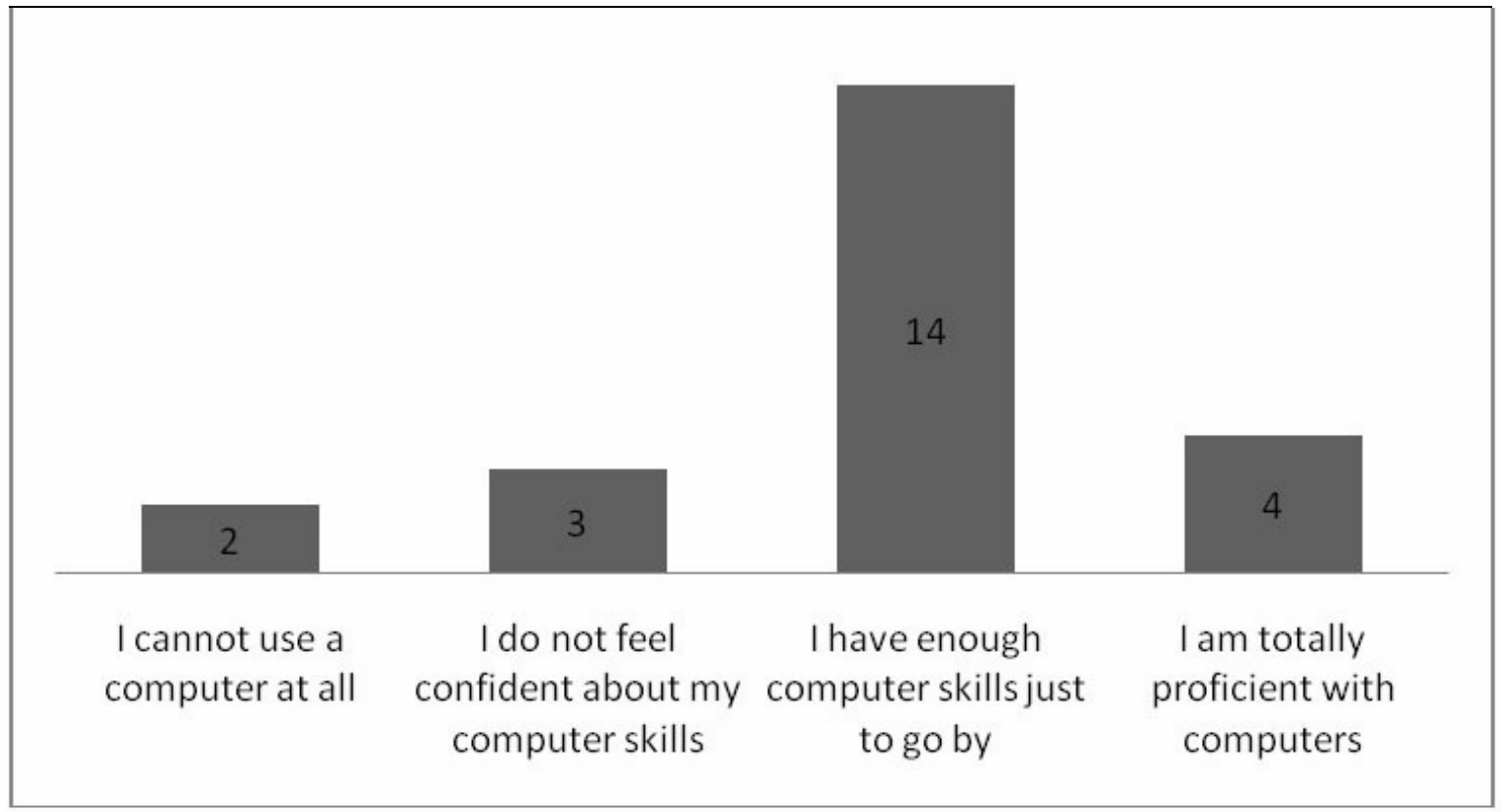

Figure 5 Competencies of Lawyers with computers $(\mathrm{N}=23)$

Intranets were the least known tools to most of the lawyers, represented by $8(35 \%)$ respondents (Table 2$)$. The fact that there were some participants, who did not provide answers to some of the questions, reveals that they were unfamiliarity with some of the concepts applications on the part of some participants. The respondents were also requested to choose one answer statement from the four possibilities provided to indicate their competencies in the use of computers. The results showed that 14 (6I\%) of respondents had adequate computer skills to get by, 4 (I7\%) were totally proficient with computers; 3 (I3\%) respondents did not feel confident about their computer skills; and 2 (9\%) cannot use a computer at all (figure 5). 
Assessment of knowledge and competencies of lawyers about computers was also done because a person who is competent in information technology application or system is more likely to use that application or system, than the one who does not know anything about it. According to Western et al (200I:10), people with limited computer experience and skills are less inclined to use computers than those who have that experience and skills. The study conducted by Fombad and Moahi (2005:23I) also found that lack of in-house expertise was rated as the strongest factor that hinders the adoption and use of information technology.

\subsection{Information and KM culture}

Section $E$ of the questionnaire solicited information about the extent to which the respondents engaged in discussions about I and KM tools and activities amongst themselves. Most of the respondents, that is, 9 (40\%) expressed the view that $\mathrm{I}$ and KM tools and activities were infrequently discussed in their law firms. This was followed by 6 (26\%) respondents who stated that I and KM technologies were never discussed or assessed in their firms. Those who said that these technologies were hardly ever discussed constituted 4 (17\%) of the respondents, whilst 3 (13\%) respondents said they were frequently discussed and I (4\%) respondent indicated that almost always were information and knowledge management tools discussed. These results (figure 6) revealed the non-existence of positive culture towards I and KM technologies by the participants.

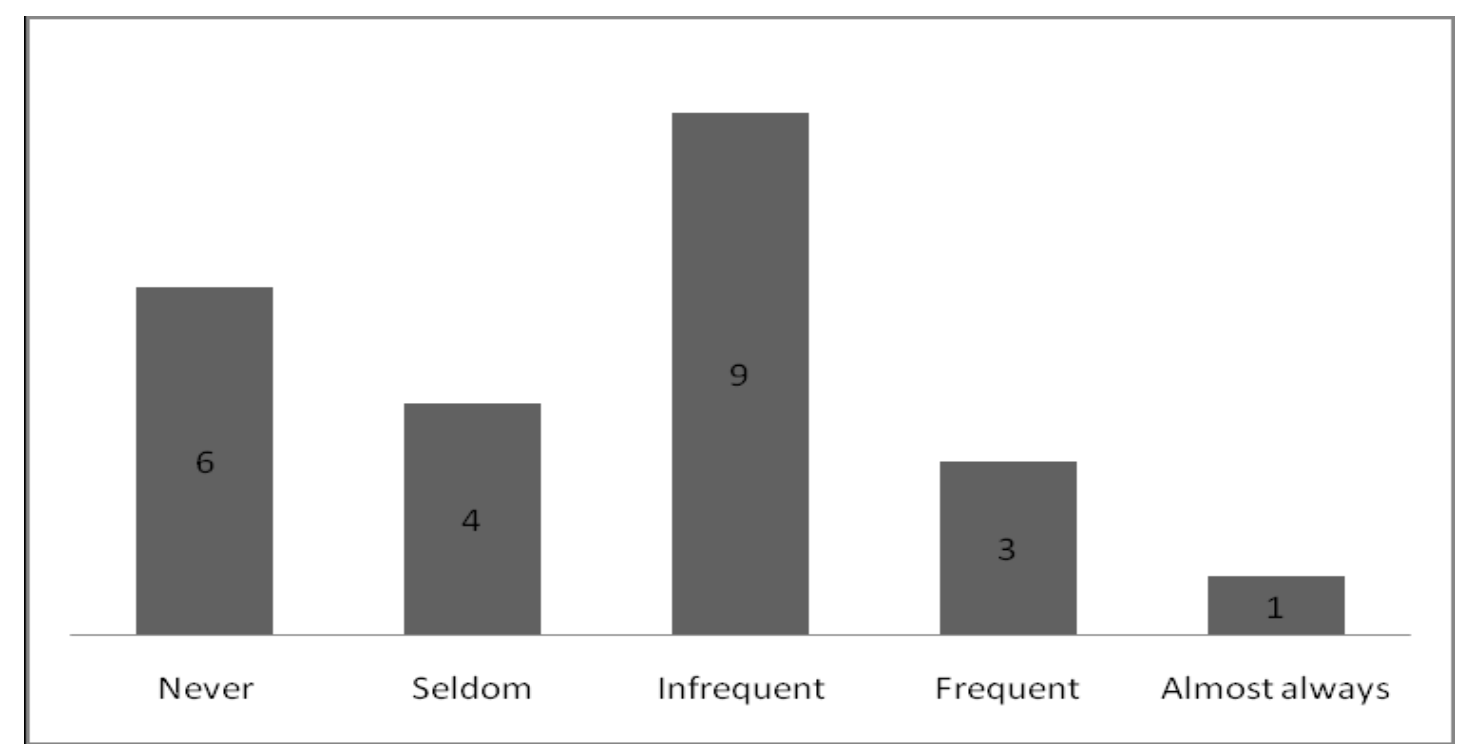

Figure 6 Frequency at which information and were discussed or assessed $(\mathrm{N}=23)$

Ndlela and Du Toit (2005) maintain that it is important to consider the type of culture residing within an organization, since the cultural habits of members of an organization affect the way in which it could persuade or discourage individuals to make use of $I$ and KM tools. Culture towards I and KM programmes will involve the way in which the law firm persuade utilization of information and knowledge to meet the objectives of a law firm. Law firms where I and KM technologies and activities are always discussed and come top of the agenda in meetings, are likely to utilize the tools. Saylor (2004: 46) declared that the biggest obstacles to law firm I and KM are insufficient support from firm leadership.

\section{Conclusion and recommendations}

Lawyers attached to law firms in Polokwane city are poor users of information technology not because of ignorance, but because of various factors. Firstly, most of them come from rural areas, where they were not exposed to computers. Secondly, most lawyers have studied their legal degrees a long time ago, in an educational environment where information technology skills were not part of the curriculum. Consequently they did not acquire computer skills that are required from them when they assume responsibility as legal professionals. Thirdly, most of the law firms to which they are attached are very small; therefore, they do not have sufficient financial resources to purchase sophisticated 
technologies and to employ people responsible for I and KM activities and functions. It was also established that lawyers utilise information technology systems or applications that are common, such as word processing, e-mail, searching legal information, case management, and client billing. I and KM tools, such as Intranets, extranets and web portals, were not used by most of the law firms in the area. The main reason for non-utilization of such systems is unfamiliarity with web technologies. The attitudes of lawyers towards application of information technology in law firms were positive, but the only problem that is holding them back from exposing their positive attitudes towards information technology was their unfamiliarity with I and KM tools.

The findings of this study have some remarkable implications for the legal education. Most law schools offer little or no formal technology skills training to their students. In most universities, law students learn about information technology on their own (Bennet 2006). The focus for legal education in most universities has traditionally been only on the academic content of courses. Today, emphasis should also be placed on the use of information technology as well as role of I and KM in law firms in the law school curriculum. The new generation of lawyers currently leaving the law schools are being raised in an era of computers. It is anticipated that the level of expectations and reliance on sophisticated approaches to information will be very high. Law schools should realise that including technology modules in the legal curriculum is an essential part of attracting and retaining the best talent for future law firms.

In order to provide competent legal services to their clients, lawyers will have to learn new skills and acquire new knowledge that has been absent from the curriculum of the traditional law schools. This can be done by providing inhouse training to the lawyers on the use of information technology in their profession. Since most of the lawyers might not have time to attend training, it is also recommended that they employ the services to the technical expert to assist them in the adoption of information technology and its use in their law firm.

Future research can be undertaken in other cities in South Africa to determine the usage of information technology by lawyers. The utilisation of information technology by lawyers in Polokwane might not be the same as in the other cities belonging to other provinces such as Pretoria and Johannesburg in Gauteng Province. There should be a number of variables that are attributable to the difference in information technology usage by lawyers in various provinces of South Africa. Developments in information technology are also not static; hence the use of information technology by lawyers will not remain the same. New information and knowledge management software and technologies or tools may be developed; hence the utilisation levels and behaviour of information technology by lawyers might also change. Future research could, for example, be conducted on how lawyers utilize web.2.0 technologies in their firms.

This work did not cover the utilization of information technology in court proceedings. Future research could, therefore, also be conducted on the utilization of information technology by attorneys, not only in their law firms but also in the court room. This study was based on only one model theoretical background; viz.,TAM. Other studies could still be conducted, based on other models or a combination of all models. Future research is also recommended on the usage of information technology among lawyers belonging to different sectors so as to find out if there are any prevailing differences.

\section{References}

Al-Gahtani, SS \& King, M. 1999. Attitudes, satisfaction and usage: factors contributing to each in the acceptance of information technology. Behaviour and Information Technology, 18(4): 277-297.

Archbold, CW. 1998. A survey of TCP/IP based application as enablers of business processes transformation in South African attorney's firm. Unpublished dissertation, Masters in Business Administration Dissertation, University of Cape Town.

Bennet, SR. 2006. Teaching tech skills to lawyers. The National Law Journal. [Online] http://www.law.com/jsp/law/ LawArticleFriendly.jsp?id= I / 37665 I09054. (Accessed I 2 July 2007).

Botha, DF \& Fouche, B. 2002. Knowledge management practices in the South African business sector: preliminary findings of a longitudinal study. South African Journal of Business Management, 33(2): 13 - 19.

Cascio, WF. 200I. Knowledge creation for practical solutions appropriate to a changing world of work. Journal of Industrial Technology, 27(40): 14 - 16.

Cloete, M., \& Snyman, RMMM. 2004. Are enterprice portals- knowledge management? South African Journal of Libraries and Information Science. 70(I): 47-57.

Codrington, G. 2004. Mind the generation gap. Journal of Marketing, I0(16): 36-37.

Colvin, CA. \& Goh, A. 2005. Validation of technology acceptance model for police. Journal of Criminal Justice, 33: 89-95.

Davis, FD. 1989. Perceived usefulness, perceived ease of use, and user acceptance of information technology. MIS Quarterly, September: $319-339$.

Duncan, P. 1997 The impact of IT on small legal practices in Scotland. Journal of Information, Law and Technolog. [Online]. http:// elj.warick.ac.uk/jilt/wip/97_I dunc/abstract.htm. (Accessed 29 July 2004).

Du Plessis, M \& Boon, JA. 2004. Knowledge management in e-business and customer relationship management: South African case study findings. International Journal of Information Management, 2 I (I): 73-86.

Du Plessis, T. 2004. Information and knowledge management in support of legal research in a digital environment. Unpublished Doctoral Thesis, Department of Information Science, Rand Afrikaanse University. 
Du Plessis, T \& du Toit, ASA. 2005. Survey of information and knowledge management in South African law firms. South African Journal of Information Management, 7(I). [Online]. http://www.sajim.co.za. (Accessed I I May 2005).

Du Plessis, T., \& du Toit, ASA. 2006. Knowledge management and legal practice. International Journal of Information Management, 26(5): 360-37I.

Du Toit, ASA. 2003. Competitive intelligence in the knowledge economy: What is in it for South African manufacturing companies? International Journal of Information Management, 23(2): I I I I 20.

Edwards, DL. \& Mahling DE. 1997. Toward knowledge management systems in the legal domain. Proceedings of the International ACM SIGGROUP Conference on supporting group work: The Integration Challenge, Phoenix, Arizona, United States, pp. I58- 166.

Fishbein, M \& Ajzen, I. 1975 Belief, attitude, intention and behaviour: an introduction to theory and research. London: AddisonWesley Publishing Company.

Fombad, M \& Moahi, K.H. 2005. Perceptions of Botswana lawyers about the use of ICTs in law firms in Botswana. South African Journal of Libraries and Information Science, 7I(3): 225 - 233.

Gottschalk, P. 2002. Stages of growth model for knowledge management technology in law firms. The Journal of Information. Law and Technology, 2. [Online]. http://elj.warwick.ac.uk/jilt/02-2/gottschalk.html. (Accessed 28 April 2004).

Griffith, C. 1998. Web technology and today's law offices. Information Today, I5(I): I4 - I5.

Hofman, J. 1997. Is there free lunch on the Internet? [Online] http://www.derebus.org.za/scripts/. (Accessed 29 March 2004).

Jenkins, J. 2008. What can information technology do for law firms? Harvard Journal of Law and Technology, 21 : 589

Kennedy, D. 2002. Law firms play catch-up: key legal technology trends for 2002. [Online]. http://www.llrx.com/features/ techtrends2002.htm. (Accessed I August 2004).

Meyerowitz, SA. 2003. Use of law firm intranets is growing, New Jersey Law Journal. [Online]. http://wwww.law.com/jsp/law/ LawArticleFriendly.jsp? I = 1046833537480. (Accessed I 3 July 2007).

Ndlela, LT \& du Toit, ASA. 200 I. Establishing a knowledge management programme for competitive advantage in an enterprise. International Journal of Information Management, 2I(2): I5I - I65.

Mountain, DR. 2002. Could new technologies cause great law firms to fail? Syracuse Law Review, 52: I065-I08I.

Newman, V. 1999. Limitations of knowledge management. South African Journal of Information Management, I (I). [Online]. http://general.rau.ac.za/infosci/raujournal/voll.nrl. (Accessed I0 September 2003).

Parson, M. 2004. Effective knowledge management for law firms. Oxford: Oxford University Press.

Riley, D. 2005. The provision of information services to attorneys. OSALL Newsletter. 16 (3). Also presented at OSALL 2005 Annual General Meeting.

Saylor, GM. 2004. Building the case for knowledge management. Law Practice and Management, 46(I): 46-48.

Schlein, LC. 2003. Using technology to remain competitive. New Jersey Lawyer, May 5. [Online]. http://www.ghostdigest.co.za/ code/A_2I8.html. (Accessed 7 July 2008).

Shuey, PJ. 1990. Software basics for every lawyer. Management Solutions, July: 90.

Singh, G., O' Donoghue, J \& Broome, K. 2002. An empirical study in the use of IT by small and large legal firms in the UK. The Journal of Information, Law and Technology, I. [Online]. http://elj.warwick.ac.uk/jilt/02-I/singh.html. (Accessed 7 July 2008 ).

Staudt, RW. 2003. White Paper on Perspectives on Knowledge Management in Law Firms. LexisNexis.

Steyn, T. 2003. Creating Knowledge-based organizations by means of knowledge management and organizational learning, Acta Academia, 35(I): $206-228$.

Tseng, S. 2008. The effects of information technology on knowledge management systems. Expert Systems with Applications, 35: I50-160.

Venkatesh, V \& Bala, H. 2008. Technology acceptance model 3 and a research agenda on intervention. Decision Sciences, 39(2): 273-3I5.

Wall, DS. 1998. Information technology and the shaping of the legal practice in the UK. Paper presented at the $13^{\text {th }}$ BILETA Conference: The Changing Jurisdiction, Trinity College, Dublin. [Online]. http://www.bileta.ac.uk./98papers/wall.html. (Accessed 23 June 2004).

Wall, DS \& Johnstone, J. 1997. Lawyers, information technology and legal practice: the use of information technology by provincial lawyers. International Review of Law, Computers and Technology, I I ( I): I I 7 - I 27.

Western, M., Dwan, K., Makkai, T., Del Mar, C \& Western, J. 200I. Measuring IT use in Australian general practice. General Practice Computer Group.

Whitcare BE. 20I0. The diffusion of internet technologies to rural communities: a portrait of broadband supply and demand. The American Behavioural Scientist, 53(9): 1283

Widdison, R. 1995. Lawyering on the Internet. [Online]. http://webjcli.ncl.ac.uk/articles/widdisI.html. (Accessed 25 April 2005). 